\title{
RESISTENCIA Y ESPERANZA EN EL QUEHACER DOCENTE
}

Xinia Salmerón Alpízar

En uno de los diarios nacionales encuentro un nuevo artículo sobre la educación costarricense. Lo leo con interés y a la vez con inquietud: con interés porque, para mí, la educación no solo es un tema sobre el cual deberíamos opinar, sino porque es parte de mi vida de mis preocupaciones cotidianas. Ella, siendo el terreno de mi actividad profesional me absorbe y me permite una muy cercana comunicación con los demás.

Soy educadora por excelencia y, como tal, poseo un sentimiento común con mis colegas. En los últimos años, se nos ha agredido una vez y otra también. ¿Qué pasa? ¿Por qué, frente a esa tendencia por "bajarnos el piso", no reaccionamos y nos defendemos? ¿Estamos tan inmersos en exámenes, planeamientos, papeleos y rutinas, que solo tenemos tiempo para desahogarnos comentando entre nosotros, con resentimiento y frustración, la forma en que nos tratan? 
No hay tiempo ni espacio para más: en el recreo, en la sala de profesores, a la hora de la salida, quizás dejamos volar un "ino es justo!", pero continuamos cargando nuestra cotidianidad de papeleos, exámenes, tareas por revisar y "control" de 40 estudiantes por grupo, que entran y salen de nuestras aulas cada 80 minutos, durante horas y horas del día, hasta sumar ¿trescientos?, ¿cuatrocientos?, ¿quinientos muchachos y muchachas?, día a día y semana a semana.

Siempre he querido expresar mis inquietudes y sentimientos en relación con la imagen del educador costarricense, en general, y del que imparte sus lecciones en la escuela secundaria, en particular, porque es ahí donde he laborado siempre; manifestarme en algún medio de comunicación, como respuesta a los múltiples escritos que salen constantemente en los periódicos. Nunca lo he hecho por diversas razones: falta de tiempo, evasión para no enfrascarme en una discusión inútil con personas que, ignorantes de la verdadera faena cotidiana que realiza el profesor en las aulas, emiten su opinión sin ton ni son, ensañándose de la manera más inconsciente con uno de los tantos elementos curriculares, el educador, que influyen en la educación costarricense. El supuesto, para esta gente, es que absolutamente todo es culpa del educador. Antes que nada, debe "obligarse a los educadores a cumplir": si los estudiantes no aprueban, es culpa de la vagabundería de los educadores; si los 200 días no se cumplen a cabalidad, es culpa de los educadores.

Hoy he sacado un ratito de ese tiempo saturado queriendo externar también mi opinión; ¿tengo derecho a hacerlo?, ¡claro que sí! Me lo he ganado al acumular años y años de experiencia y entusiasmo, poniendo mi mayor empeño en las aulas de colegio. Sé de las vicisitudes y obstáculos de esta profesión, pero también de las lindas experiencias que se viven y que no te dejan mucho tiempo 
para hacer crítica periodística. Me lo he ganado al conocer de cerca la labor de familiares muy cercanos, educadores también que, en su afán diario, han puesto su mejor esfuerzo en las aulas de escuelas y colegios; labor silenciosa y desgastante, pero plena de satisfacciones al cosechar frutos intangibles como son los de la aventura de enseñar y de aprender. Me lo he ganado, porque tuve la oportunidad de convivir y disfrutar de esa aventura a la par de mis maestras de escuela, principalmente escultoras de mi gusto por el estudio, mi disciplina de trabajo y lo más importante, de mis principios y valores; de profesores y profesoras de colegio a quienes admiré y me sirvieron de ejemplo, ya desde mi adolescencia y juventud. Es cierto, hubo algunos "de cuyo nombre no quiero acordarme", pero, dichosamente, fueron los menos.

A los educadores nos agobian muchas rutinas y trabajos que no son parte de nuestra función esencial: el acompañamiento de los jóvenes en el logro de sus aprendizajes. Son exigencias, ocurrencias, trámites burocráticos, muchas veces innecesarios, que ya casi no nos permiten siquiera disfrutar del trabajo. Claro, el trabajo debe disfrutarse; es una bendición, un derecho, un privilegio, sobre todo cuando se lleva a cabo con niños y jóvenes. Pero, en la realidad, el sistema está agobiando al educador, lo está anulando, asfixiando. Si hay que atender a 500 o más estudiantes, con un horario que incluye las lecciones en el colegio y otro tiempo igual de trabajo en la casa revisando trabajos y exámenes, no hay tiempo para el crecimiento intelectual, ni para dedicarle un rato al ocio, ni para contestar los ataques o reflexionar sobre la crisis educativa: estamos condenados solo a cumplir y cumplir y cumplir con las "obligaciones".

Nos estamos convirtiendo en máquinas de revisión, midiendo, desarrollando contenidos, no importa si se disfruta o no el aprendizaje, si se aprende o no. Casi se desea 
que el educador no piense, que solo ejecute órdenes. Lo importante únicamente parece ser cumplir con el programa, derretir las horas lectivas para que los estudiantes alcancen la nota para pasar.

El rendimiento académico estudiantil es prioridad social: esos números que indiquen que la mayoría sube al nivel siguiente. En el fondo, el estudiante, la persona que representa, no interesa. Si el estudiante obtuvo un 6,40 no vale, así sea que su esfuerzo, su experiencia de aprendizaje y su formación en valores, hayan sido enormes por intentar alcanzar ese 6,40. Esto puede ser frustrante si los profesores creemos plenamente en que nuestra función es, como dice la Ley Fundamental de Educación, formar personas amantes de su patria, conscientes de sus deberes y derechos, tolerantes y respetuosos de los derechos de los demás.

Como formadores de personas, estamos perdidos. Perdida queda nuestra vocación si continuamos realizando nuestro trabajo a destajo. Entonces, ¿qué hacemos? ¡Hay que cumplir, porque el Ministerio lo exige, porque el Comité de evaluación lo exige, porque los padres de familia lo exigen! Eso es, elevar el rendimiento académico, lograr que esos 40 estudiantes que pasan por mi aula durante 80 minutos, o esos 500 estudiantes al día, alcancen notas de 70 para arriba. No hay tiempo ni capacidad para enseñar a pensar. Si no atendemos personas, sino masas, entonces, la mejor opción es que repitan lo que les exponemos, que copien lo mejor posible lo que el programa de estudio dice, y ya. Si cumplimos con el programa y con el supremo 70 , la sociedad estará satisfecha.

Guardemos nuestra frustración, dejémonos de sensiblería y de vocación como formadores de personas. La realidad no nos permite soñar. Como se escucha en los corrillos educativos: ya los apóstoles de la educación no existen y si intentaran volver, los absorbería el sistema o se volverían a sus tumbas horrorizados. 
La angustia no nos abandona. "Cumpliendo con nuestro deber" a regañadientes, sin creer mucho en lo que hacemos, nos enfermamos. Quien no cree en lo que hace, quien no trabaja poniendo toda su fe y entusiasmo en la labor que ejerce, convierte ese trabajo en un lastre que hay que arrastrar, no disfrutar. Vuelve, entonces, esa frustración, las enfermedades físicas y mentales, como una reacción del organismo al agobio de cumplir con el deber, sin querer ni creer en lo que se hace. Porque, finalmente, no es precisamente lo que creíamos que íbamos a ser: formadores de personas, fomentar valores, acompañar a los niños y jóvenes en su proceso de aprender, ipor Dios!

Entonces, aparece en las noticias otro artículo, ahora sobre el exceso de incapacidades de los educadores, su vagabundería, su abuso. Más frustración, puesto que ni siquiera hay derecho a enfermarse. ¡Bueno!, existen algunos educadores que con tal de escapar de su realidad, inventan enfermedades físicas, es cierto; así las cosas, ¿no es esto signo de desequilibrio mental, de deterioro?

Pero, claro, no está en la actitud conformista y derrotista la solución al problema sobre el cual es la mejor forma de realizar nuestras tareas educativas y desenvolvernos como buenos profesionales. ¿Cuál es la solución? ¿Somos los educadores el problema? ¿Somos parte del problema? ¿Podríamos ser parte de la solución? ¿Cómo podríamos ser parte de la solución? Esta es una pregunta vital, tanto para lograr una mejor calidad de la educación, como de la calidad de vida de los educadores, de los estudiantes y de la sociedad costarricense.

Los educadores costarricenses somos una parte importante de esa sociedad. Creo, firmemente, en que debemos inspirarnos y buscar nuestra propia liberación, como profesionales, en los inicios de la educación costarricense, precisamente allá donde se encuentran olvidados los apóstoles 
de la enseñanza. Para ser educadores debemos tener vocación, conocer claramente cuál es nuestra función primordial: formar personas. Lo dice nuestra Ley Fundamental de Educación: mantenernos por encima de la burocracia, de las modas pedagógicas, de la presión del sistema. Debemos respetarnos y exigir que nos respeten como gestores de ideas, con autonomía y criterio para opinar y actuar en nuestro campo laboral específico: la educación. Debemos hacernos sentir, darnos a conocer ante la opinión pública. Ha sido por esta convicción que decidí escribir esta carta. 